\title{
Indian Python (Python molums) as Prey of a Freshwater Crab (Brachyura: Gecarcinucidae: Barytelphusa sp.)
}

\author{
Raju Vyas ${ }^{1}$ and Kartik Upadhayay ${ }^{2}$ \\ 1Fatehgunj, Vadodara, Gujarat, India (razoovyas@hotmail.com) \\ ${ }^{2}$ Ellora Park, Vadodara, Gujarat, India \\ Photographs by the second author.
}

$\mathrm{F}$ reshwater crabs (Decapods: Brachyura) prefer to remain hidden during the day in sheltered places and forage mostly at night. They are adapted to a freshwater, semi-terrestrial, or terrestrial mode of life and are known for their ability to complete their life cycles independently of the marine environment. They are found in almost any freshwater habitat, including streams, pools, ponds, rivers, swamps, rice fields, rock holes/pits, tree trunk holes, and even leaf axils. They are mostly omnivorous scavengers and feed primarily on plant matter. Some are opportunistic carnivores, taking live prey such as fish and prawns and dead animals encountered fortuitously; cannibalism is not uncommon ( $\mathrm{Ng} 1988)$. A few publications report freshwater brachyurans sporadically predating various stages of anuran amphibians (e.g., Hayes 1983; De Silva 1997; Gray and Christy 2000; Tsuji 2005; Affonso and Signorelli 2011) and one report describes marine crabs attacking frogs (Pyke et al. 2013). Considering these food habits, we observed an unusual predation behavior of freshwater crabs at Bhat Forest, Jambughoda Wildlife Sanctuary (JWS).

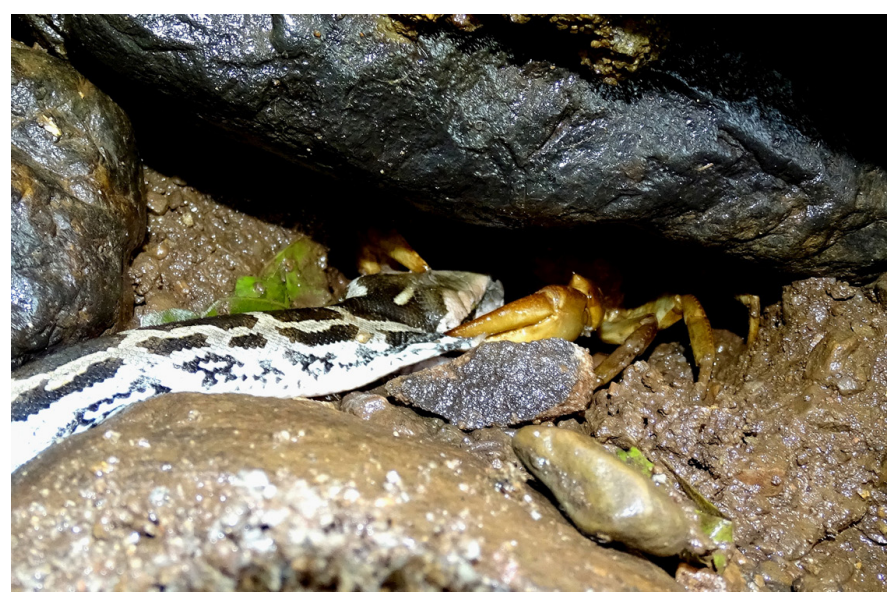

Fig. 1. Head of a hatchling Indian Python (Python molurus) in the firm grip of a freshwater crab (Barytelphusa sp.).
The JWS, partly in the Panchmahals and Vadodara Districts, Gujarat State, India $\left(22^{\circ} 20^{\prime}-20^{\circ} 33^{\prime} \mathrm{N}, 73^{\circ} 35^{\prime}-\right.$ $73^{\circ} 45^{\prime} \mathrm{E}$ ), covers $130.38 \mathrm{~km}^{2}$, ranges in elevation from 230 to $354 \mathrm{~m}$ above mean sea level, and is classified as Southern Tropical dry deciduous forest (Champion and Seth 1968). The reptilian fauna of the sanctuary is moderately rich (Padate 2006); 13 families and 28 reptilian species, including the Indian Python (Python molurus), have been recorded from the sanctuary (Vyas 2006).

In the evening of 15 August 2015 between Ghaghar Mata and Bhat Village, we observed a few crabs foraging in the shallow waters of a small intermittent stream with a rocky boulder substrate $\left(22^{\circ} 23^{\prime} 45.05^{\prime \prime} \mathrm{N}\right.$; 7337'20.00”E). We also saw tadpoles, adult frogs (Indian Skippers, Euphlyctis cyanophlyctis, and Asian Bullfrogs, Hoplobatrachus tigerinus), small fishes (Spotted Barbs, Puntius sp.), and a hatchling Indian Python. In response to our presence, all of these little creatures hid under rocks or boulders, except the python. Intrigued by its unusual behavior, we carefully moved closer

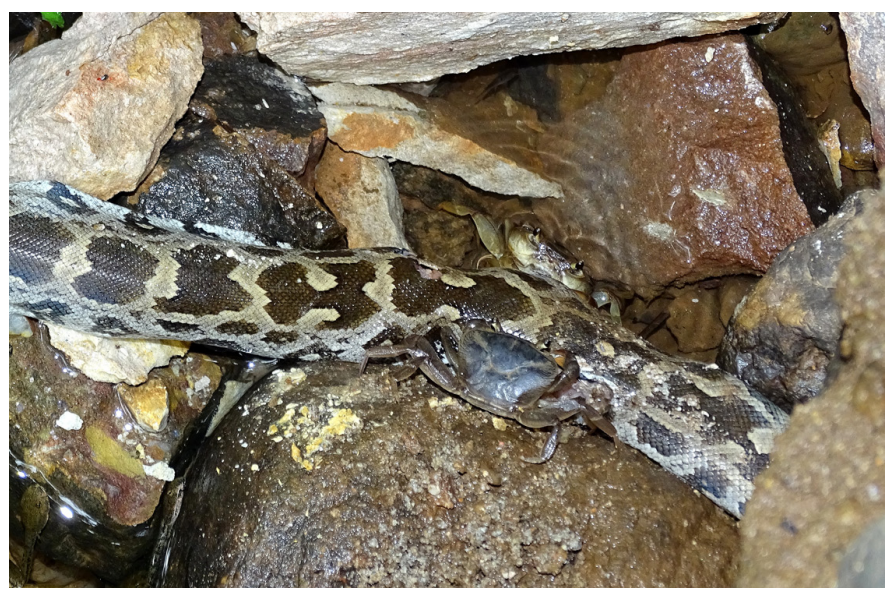

Fig. 2. Freshwater crabs (Barytelphusa sp.) feeding at midbody on a hatchling Indian Python (Python molurus). 


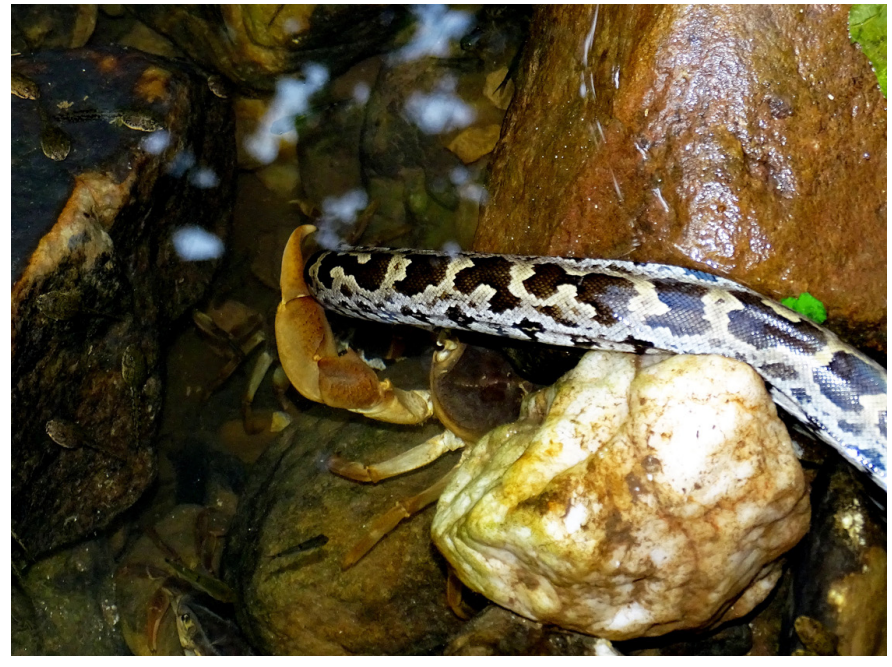

Fig. 3. The posterior portion of a hatchling Indian Python (Python molurus) grasped by the cheliped of a freshwater crab (Barytelphusa sp.).

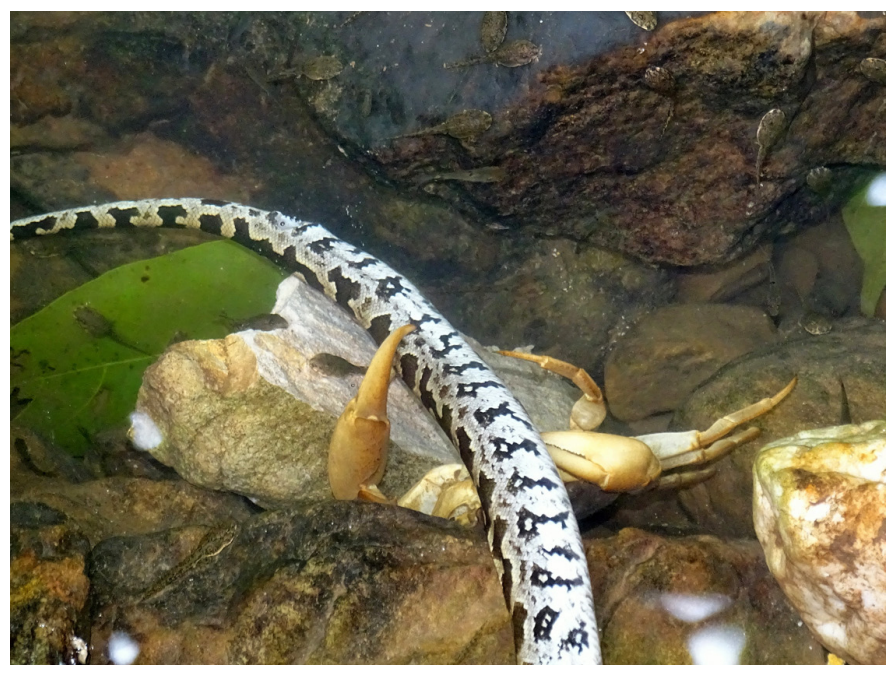

Fig. 4. The tail of a hatchling Indian Python (Python molurus) held by the cheliped of a freshwater crab (Barytelphusa sp.).

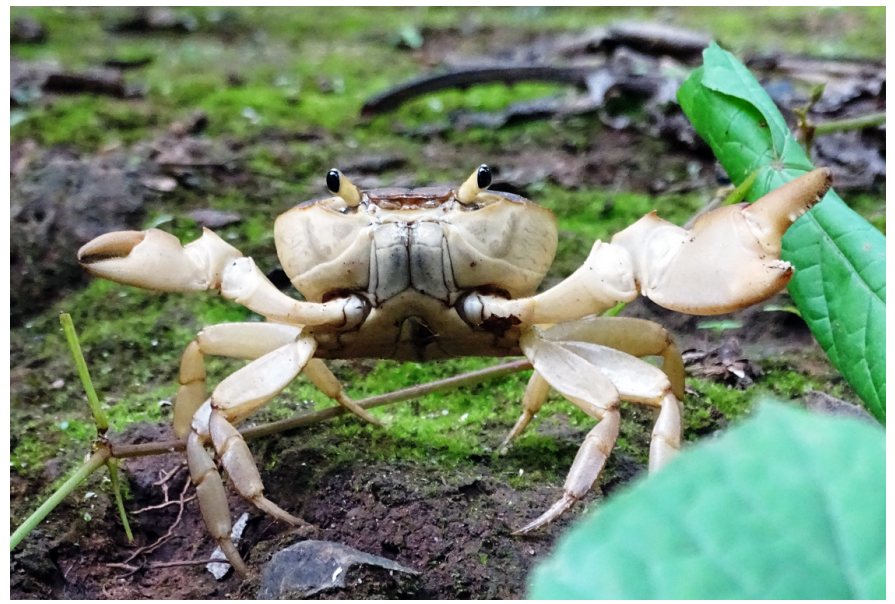

Fig. 5. A freshwater crab (Barytelphusa sp.) such as those observed preying on a hatchling Indian Python (Python molurus). and discovered an adult crab (Barytelphusa sp.) holding the head of the python with its two large chelipeds (Fig.1), two other adult crabs hanging onto and vigorously "biting" the middle portion of snake's body (Figs. 2-3), and two or three additional crabs attacking the python's tail (Fig. 4). During the next three hours, we watched the crabs devour the python. Toward the end, they were trying to drag their prey beneath the rocks. By the time we left, after four hours of continuous observations, we counted another six or seven large crabs that had joined the feast. We estimated that the python was no more than 2-3 days old and about $50-55 \mathrm{~cm}$ in body length. The next morning, we found no evidence of the event.

Female Indian Pythons usually lay eggs in March-April, and 50-60-cm long hatchlings emerge after a two-month incubation period (Vyas 2002; Whitaker and Captain 2004) in July-August. Neonates, because of their small size, are particularly vulnerable to predation.

After identifying the crab as Barytelphusa sp. (Fig. 5) using Bahir and Yeo (2007) and Yeo et al. (2008), we found only one record of brachyuran decapods preying on a reptile, a Checkered Keelback (Xenochrophis piscator) eaten by freshwater crabs at Dholha Ghuna, Barda Wildlife Sanctuary, Gujarat (R. Vyas, unpubl. obs.). Like P. molurus, X. piscator is closely associated with aquatic habitats, suggesting that predation events such as these might be more common than the literature would suggest.

\section{Acknowledgements}

We are grateful to the Deputy Conservator of Forests, Gujarat Forest Department, Vadodara for help during our visit to the Jambughoda Wildlife Sanctuary, and to Mr. J.N. Trivedi for help with the identification of the crab and for providing relevant literature. Special thanks to Reshma Solanki (Vadodara) for accompanying us in the field.

\section{Literature Cited}

Affonso, I.D.P. and L. Signorelli. 2011. Predation on frogs by the introduced crab Dilocarcinus pagei Stimpson, 1861 (Decapoda, Trichodactylidae) on a Neotropical floodplain. Crustaceana 84:1653-1657.

Bahir, M.M. and D.C.J. Yeo. 2007. The gecarcinucid freshwater crabs of southern India (Crustacea: Decapoda: Brachyura). The Raffles Bulletin of Zoology, Supplement 16:309-354.

Champion, H.G. and S.K. Seth. 1968. A Revised Survey of the Forest Types of India. Government of India, New Delhi.

De Silva, A. 1997. Crab feeding on a tadpole. Lyriocephalus 2:28.

Gray, H.M. and J.H. Christy. 2000. Predation by the grapsid crab, Armases angustum (Smith, 1870), on tadpoles of the Green Poison Frog, Dendrobates auratus Girard, 1855. Crustaceana 73:1023-1025.

Hayes, M.P. 1983. Predation on the adults and prehatching stages of Glass Frogs (Centrolenidae) Biotropica 15:74-76.

Ng, P.K.L. 1988. The Freshwater Crabs of Peninsular Malaysia and Singapore. Department of Zoology, National University of Singapore, Shinglee Press, Singapore.

Padate, G. 2006. Ecological Faunal Diversity Study of Jambughoda Wildlife Sanctuary, Final Report, Faculty of Science, M.S. University of Baroda, 
Vadodara-390002. Submitted: Gujarat Forest Department, Gandhinagar, Gujarat. 90pp. (Unpublished Report).

Pyke, G.H., S.T. Ahyong, A. Fuessel, and S. Callaghan. 2013. Marine crabs eating freshwater frogs: Why are such observations so rare? Herpetology Notes 6:195-199.

Tsuji, H. 2005. Predation on a fanged frog (Limonectes kublii) by a Freshwater Crab (Candidiopotamon rathbuni). Herpetological Review 36:125-127.

Vyas, R. 2002. Breeding data on captive Indian Rock Python (Python molurus molurus). Zoos' Print Journal 17:752-756.
Vyas, R. 2006. Reptilian diversity of Jambughoda Wildlife Sanctuary, Gujarat. Tigerpaper 33(1):20-23.

Whitaker, R. and A. Captain. 2004. Snakes of India - The Field Guide. Draco Books, Chennai, India.

Yeo, D.C.J., P.K.L. Ng, N. Cumberlidge, C. Magalhaes, S.R. Daniels and M. Campos. 2008. A global assessment of freshwater crab diversity (Crustacea: Decapoda: Brachyura). In: E.V. Balian, C. Lévequè, H. Segers, and M. Martens (eds.), Freshwater Animal Diversity Assessment. Hydrobiologia 595:275-286. 